\title{
MITES ASSOCIATED WITH BEES IN JAMMU AND KASHMIR, INDIA
}

\section{B.N. Putatunda ${ }^{1}$ and D.P.Abrol ${ }^{2}$}

\author{
${ }^{1}$ Department of Zoology, Haryana Agricultural University, Hisar, \\ Haryana 125004, India. \\ Presently Department of Entomology, CCS Haryana Agricultural \\ University, Hisar, Haryana 125004, India. \\ ${ }^{2}$ Department of Entomology, S.K. University of Agricultural \\ Technology, Jammu, Jammu \& Kashmir, India.
}

Jammu and Kashmir, the northern most state of India with the climate subtropical in Jammu and temperate in Kashmir. The local population is basically farmers who have been practicing bee keeping with the local species, i.e. Apis cerana indica. Modernization of agriculture has led some bee keepers to adopt the European species of honey bee A. mellifera. The role of solitary bees /non Apis bees as efficient pollinators is being realized lately. This paper presents the mites associated with bees in the state of Jammu and Kashmir.

The mites encountered on different bees are presented in Table 1. The bee mite, Varroa jacobsoni, first described by Oudemans (1904a,b) is presently the most important enemy of bee keeping industry throughout the world including developed and underdeveloped countries (Percy \& Kshirsagar, 1964; Delfinado \& Baker 1974; Harnaj, 1977; Griffith \& Bowman 1981; Dejong et al., 1982; Kapil \& Putatunda, 1983; Ritter, 1986; Tibor, 1988; Putatunda, 1996; Bobhorr, 1998; Erickson et al., 1998; Putatunda etal., 2001).

The mite Euvarroa sinhai was originally described by Delfinado and Baker from India in 1974 on Apis florea and then was recorded extensively in Haryana State mainly on A. florea and later on A. mellifera (Bhaskar \& Putatunda, 1989; Putatunda 1996) and from Jammu \& Kashmir (Abrol \& Putatunda, 1995). This mite will be a great cause of concern to the bee keeping industry if it adopts A. mellifera as its host.

The mite Tropilaelaps clareae was described by Delfinado and Baker in 1961. Presently, it is considered as the second enemy of bee keeping in different parts of the globe including most states in India (Abrol \& Putatunda, 1995, 1996; Koeniger et al., 1983), but is the most important threat to bees in Haryana and Punjab (Bhaskar \& Putatunda, 1989; Putatunda, 1996). The mite has been recorded from J \& K by Abrol and Putatunda (1995).

As this mite is much faster in movement and has adapted to all the five species of honey bees (Apis cerana, A. dorsata, A. florea, A. laboriosa and A. mellifera), there is a chance that this mite will outnumber Varroa jacobsoni with the passage of time.

T. koenigerum was originally described by Delfinado-Baker and Baker in 1982 from Sri Lanka on Apis dorsata. Later on, the mite was recorded as a parasite of Apis dorsata and A. laboriosa in Nepal by Delfinado-Baker et al. in 1985. In India, this mite is known from Jammu and Kashmir from A. dorsata, A. cerana and A. mellifera (Abrol \& Putatunda, 1995).

The mite Neocypholaelaps indica Evans 1963, is known in India from the states of Karnataka, Kerala and Tamil Nadu on Apis cerana and Eucalyptus flowers. Neocypholaelaps spp. of mites are basically phoretic that are not parasites of bees (Percy et al. 1968; Putatunda, 1996; Ramanan \& Ghal, 1984) but they affect the normal pollen and nectar collecting capacity of bees. According to Delfinado-Baker and Baker (1983), and Baker and Delfinado-Baker (1985), seven species of mites of the genus Neocypholaelaps, namely $N$. africana Evans, N. amphullula (Berlese), N. apicola Delfinado-Baker and Baker, N. favus Ishikawa, $N$. indica Evans, $N$. novaehollandiae Evans and $N$. phooni Baker and Delfinado-Baker are associated with honey bees. Among these mites, $N$. indica is known from India, China, Nepal and Sri Lanka and N. apicola from Pakistan. The mite $N$. indica has been recorded from Jammu and Kashmir from Apis cerana, A. mellifera, A. dorsata and A. florea (Abrol \& Putatunda, 1995).

Prostigmatid mites have not been observed from Jammu and Kashmir though a good number of them have been described and recorded from Haryana (Baker \& Delfinado, 1975; Putatunda \& Kapil, 1988; Putatunda, 1996).

In the present study, among the Astigmatid mites, Carpoglyphus lactis (Linn.), Tyrophagus longior (Gervals) and T. tropicus Robertson, were found in different life stages (Larva/nymph/ adult) whereas all other species were encountered in the hypopeal or non-feeding phoretic conditions. Acarid hypopial stages are known to attach themselves to insects (Krantz, 1972). According to Prasad (1974), none of the Astigmatid mites are reported to be associated with bees in India. However, on review of bee mites of India, Putatunda (1996) indicated a large number of Astigmatid mites associated with bees in India.

The mite Carpoglyphus lactis (Linn.) is well known from food substances specially having sugars, dried fruits, rotten potatoes, fruits, pollen and even in honey combs of Apis spp. of bees and is considered as an important contaminant of honey (Baker \& Delfinado, 1978; Hughes, 1976; Krantz, 1972) in different parts of the world. In India, $C$. lactis was first recorded by Kapil et al. (1985) on Ceratina sp. of bees. 


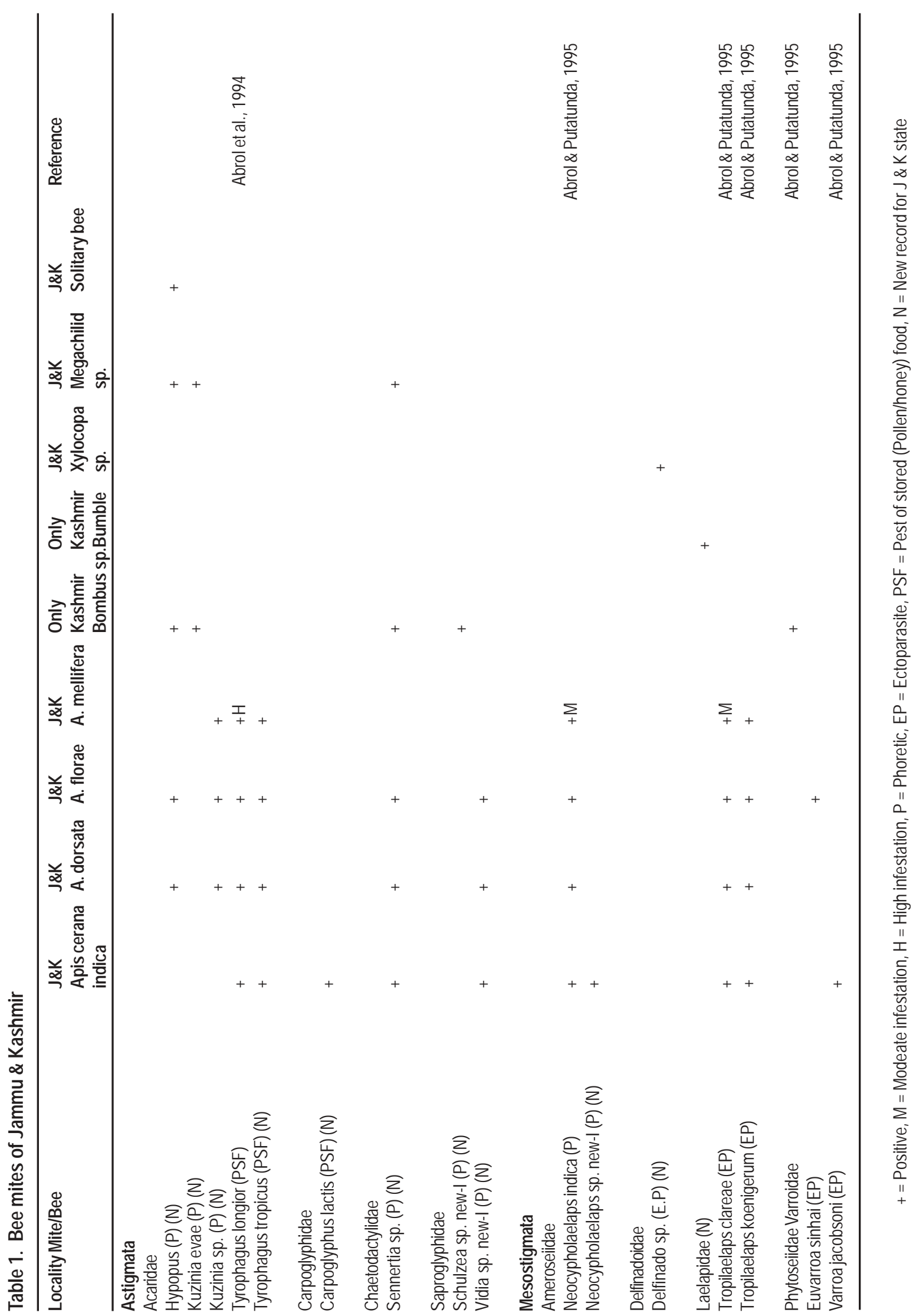


The mite Kuzinia evae was originally described by Putatunda et al. in 1983 from Pithitis sp. of bees and K. woykei the second species from India (Himachal Pradesh) on bumble bee. Prior to this, Delfinado and Baker (1976) described three new species of which $K$. dispar was based on an Indian material (the host being bumble bee).

In India, four species of Schulzea mite have been described as new species from non-Apis sp. of bees. S. zakhvatkini was described by Delfinado and Baker (1976) and other three, $S$. indica, S. orientalis and S. halicti by Putatunda and Kapil (1995).

The mite Tyrophagus longior (Gervais) was observed by Abrol et al. (1994) on bee hives of Apis cerana and Apis mellifera in Jammu and Kashmir State. According to Hughes (1976), T. longior is reported from nest of birds (sparrow) in Poland and in Poultry bed (droppings). According to Prasad (1974), T. longior and $T$. putrescentia (Schrank) are known from India mainly from decaying materials, store products, soil and in association with insects. According to De Jong et al. (1982) T. longior is known to be associated with honeybees (Apis sp.).

The mite Tyrophagus tropicus Robertson (1959) is being recorded here from all the four honey bee species namely Apis cerana, A. dorsata, A. florea and A. mellifera from Jammu and Kashmir. This mite, T. tropicus is known to infest stored products like copra, rice, tobacco, palm kernal, dust (Hughes, 1976) in USA, England, Ghana, Nigeria and in several other countries. This appears to be the first record of the mite from Asia. A related speices $T$. similis Volgin is known to infest $A$. dorsata in Haryana in India (Putatunda, 1996).

T. longior is known as causal agent of human intestinal and urogenital acariasis and that Tyrophagus sp. of mites may cause contact dermatitis to individuals who handle contaminated materials (Baker \& Wharton, 1952; Krantz, 1972).

Sennertia sp. of mites are well known to be associated with non Apis species of bees in the world (Fain, 1981; Krantz, 1972) and that 28 species have been reported from India (Putatunda, 1996; Putatunda \& Kapil, 1990). Baker and Delfinado-Baker (1983) for the first time reported the association of Sennertia mites with Apis mellifera from Guatemala.

Vidia sp. are known to be associated with bees and wasps (Baker, 1964; Delfinado \& Baker, 1976; Krantz, 1972) from different parts of the globe and from India it is known from Megachile flavipes from Haryana (Putatunda, 1996).

\section{Acknowledgement}

The authors are thankful to the authorities of the respective Universities and ICAR, New Delhi for the facilities and fund.

\section{References}

Abrol, D.P. and B.N. Putatunda (1995). Discovery of the ectoparasitic mite Tropilaelaps koenigerum Delfinado-Baker and Baker (AcariLaelapidae) on Apis dorsata L., A. mellifera L. and A. cerana F. in Jammu and Kashmir, India. Current Science 68(1): 90.

Abrol, D.P. and B.N. Putatunda (1996). New record of Tropilaelaps clarea (Acarina : Mesostigmata) associated with Xylocopa irridipennis from India. Science and Culture 62(1-2): 59.

Abrol, D.P., S.K. Kakroo and B.N. Putatunda (1994). Store product mite Tyrophagus longior (Gervals) (Astigmata: Acaridae) with hive bees in India. Current Science 66(2): 105.

Baker, E.W. (1964). Vidia cooremani, a new species of Saproglyphidae from a crabronina wasp (Acarina). Entomological News 75: 43-46.

Baker, E.W. and M.D. Delfinado (1975). A new genus of Scutacaridae (Acarina) on a bumble bee from India. U.S. Department of Agricultural Cooperative Economic Institute Report 25(19): 379-382.

Baker, E.W. and M.D. Delfinado (1978). Notes on the dried fruit mite Carpoglyphus lactis (Acarina: Carpoglyphidae) infesting honey bee combs. Journal of Apiculture Research 17: 52-54.

Baker, E,.W. and M. Delfinado-Baker (1983). New mites (Sennertia Chaetodacylidae) phoretic on honey bees (Apis mellifera L.) in Gautemala. International Journal of Acarology 9 : 117-12 1.

Baker, E.W. and M. Delfinado-Baker (1985). An unusual new species of Neocypholaelaps (Acari: Ameroselidae) from the nest of stingless bees (Apidae : Miliponinae). Intenational Journal of Acarology 11(4): 227-232.

Baker, E.W. and G.W. Wharton (1952). An introduction to Acarology. MacMillan Co., New York. 465pp.

Bhasker, S. and B.N. Putatunda (1989). Mesostigmatid mites associated with bees in India, pp 287-289. In: Channabasavana, G.P. and C.A. Viraktamath (Editors). Progress in Acarology. Vol. II. Oxford and IBH, New Delhi, 484pp.

Bobhorr, D.E. (1998). Biological control of Varroa mite without chemicals. American Bee Journal 138(11) : 801-804.

De Jong, D., R.A. Morse and G. C. Eickwort (1982). Mite pest of honey bees. Annual Review of Entomology 27: 229-252.

Delfinado, M.D. and E.W. Baker (1961). Tropilaelaps, a new genus of mite from the Phillipine (Laelaptidae: Acarina). Fieldana Zoologica 44(7): 53-56

Delfinado, M.D. and E.W. Baker (1974). Varroidae, a new family of mites on honey bees (Mesostigmata: Acarina). Journal of Washington Academic Sciences 64(1): 4-10.

Delfinado, M.D. and E.W. Baker (1976). Note of hypopi (Acarina) associated with bees and wasp (Hymenoptera). Journal of New York Entomological Society 84: 76-90.

Delfinado-Baker, M. and E.W. Baker (1982). A new species of Tropilaelaps parasitic on honey bees. American Bee Journal 122(6): 416-417.

Delfinado-Baker, M. and E.W. Baker (1983). A new species of Neocypholaelaps (Acari : Ameroseiidae) from brood combs of the Indian honey bee. Apidology 14(1): 1-7.

Delfinado-Baker, M., B.A. Underwood and E.W. Baker (1985). The occurrence of Tropilaelaps mites in brood nest of Apis dorsata and A. laboriosa in Nepal with description of the nyphal stages. American Bee Journal 125(10): 703-706.

Evans, G.O. (1963). The genus Neocypholaelaps Vitzthum (Acan: Mesostigmata). Annals of Magazine of Natural History 13(6): 209230.

Erickson, E.H., A.H. Atmowidjojo and I. Hines (1998). Can we 
produce Varroa tolerant honey bees in the Unites States? American Bee Journal 138(11) : 828-832.

Fain, A. (1981). A revision of the phoretic deutonymphs (hypopi) of the genus Sennertia Oudemans, 1905 (Acari: Astigmata, Chaetodactyliade). System Parasitology 33: 145-183.

Griffiths, D.A. and C.E. Bowman (1981). World distribution of the mite Varroa jacobsoni, a parasite of honey bees. Bee world 62(4): 154163.

Harnaj, V. (1977). Varroasis, A Honey Bee Disease. Apimondia publishing house, Bucharest, Romania, 91pp.

Hughes, A.M. (1976). The mites of storedfood and houses. Technical Bulletin of the Ministry Agriculture, London 9: 400pp.

Kapil, R.P. and B.N. Putatunda (1983). World status of mite parasitosis affecting bees. International Congress of Apiculture, Budapest (Hungary) 39: 127-128.

Kapil, R.P., B.N. Putatunda and K. Aggarwal (1985). Studies on ectoparasitic Mite of Apis species. Final Technical Report. D.S.T (198085). Department of Zoology, Haryana Agricultural University, Hissar, India, 167pp.

Koeniger, N., G. Koeniger and M. Delfinado-Baker (1983). Observations on mites of the Asian honey bee species (Apis cerana, Apis dorsata, Apis florea). Apidologie 44(3): 197-204.

Krantz, G.W. (1972). A Manual of Acarology. Oregon State University, Corvallis, 335pp.

Oudemans, A.C. (1904a). Acarologische Aanteekeningen XII Entomol. Ber. (Amst.). 18: 161-164.

Oudemans, A.C. (1904b). Note VIII on a new genus and species of parasitic acarl. Notes Leyden Museum 24: 216-222.

Percy, A.P. and K.K. Kshirsagar (1964). Occurrence of new bee mites in India. Indian Bee Journal 26(2): 27.

Percy, A.P., K.K. Kshirsagar and K. Chandran (1968). Further observations on phoretic bee mites Neocypholaelaps indica (Evans). Indian Bee Journal 30(2): 68-69.
Prasad, V. (1974). A Catalogue of Mites of India. Indira Acarcology Publishing House, Ludhiana, 320pp.

Putatunda, B.N. (1996). Bee mites in India. National Bee Keeping Experience exchange conference ICAR, PAU, Punjab pp44-50.

Putatunda, B.N.and R.P. Kapil (1988). Seven new species of Cheletophyes (Acari: Prostimata: Cheyletidae) associated with carpenter bees in India, pp. 317-328. In: Channabasavanna G.P. and C.A. Viraktamath (Editors). Progress in Acarology Vol. I, Oxford and IBH, New Delhi, 523pp.

Putatunda, B.N. and R.P. Kapil (1990). Mites associated with bees (Hymenoptera Insecta) in India. The genus Sennertia (Acari: Astigmata: Chaetodacylidae) with the description of five new species. Abstract IV National symposium on Acarology, Kerala, India. p.61.

Putatunda, B.N. and R.P. Kapil (1995). Mites associated with bees (Hymenoptera: Apoidea) in India. Three new species of Schulzea (Acari: Winterschmidtiidae). Journal of Acarology 13(1\&2): 15-21.

Putatunda, B.N., K. Aggarwal and R.P. Kapil (1983). Two new species of Kuzinia (Acarina: Acaridae) mite associated with bees (Hymenoptera) in India. Indian Journal of Acarology 8(2): 57-62.

Putatunda, B.N., K. Aggarwal and R.B. Mathur (2001). Honey bee mites (Acarina), a challenge to bee keeping industry - a review. Agricultural Review 22(3\&4): 205-214.

Ramanan, R.V. and S. Ghal (1984). Observations on the mite Neocypholaelaps indica Evans and its relationship with the honey bee Apis cerana indica Fabriclus and the flowering of Eucalyptus trees. Entomon 9(4): 291-292.

Ritter, W. (1986). Varroatosis in Honey bee Apis mellifera and its control with Perizin. Veterinary Medical Review 1 : 3 -16.

Robertson, P.L. (1959). Revision of the genus Tyrophagus with discussion on its taxonomic position in Acarina. Australian Journal of Zoology 7: 146-18 1.

Tibor, I.S. (1998). Progress report on selective breeding of honey bees for resistance to parasitic mites. American Bee Journal 138(6): 464466. 